\title{
HUBUNGAN TINGKAT STRES DENGAN GANGGUAN INSOMNIA PADA MAHASISWA/MAHASISWI BIMBINGAN PENYULUHAN ISLAM SEMESTER DELAPAN TAHUN AKADEMIK 2019/2020 IAIN PONOROGO
}

\author{
Arisma Yuli Hardiyanti \\ Fakultas Usuhulludin, Adab, dan DakwahIAIN Ponorogo \\ arismayuli8804@gmail.com \\ Lia Amalia \\ Fakultas Usuhulludin, Adab, dan Dakwah IAIN Ponorogo \\ lia.amalia@iainponorogo.ac.id
}

\begin{abstract}
This study aims to determine the level of stress and insomnia disorders experienced by BPI students in the eighth semester of the academic year 2019/2020 and to find out how stress levels relate to insomnia disorders. The variables in this study are free variables i.e. stress levels and bound variables i.e. insomnia disorders. The approach used in this study is a quantitative approach. Then the type of research is correlational. The sample used amounted to 53 respondents. The data collection technique uses questionnaires. Data analysis used using instrument tests (validity and reliability), statistical tests (descriptive statistics and inferential statistics), and contingency coefficient hypothesis tests. The results showed that the level of stress experienced by students of Islamic Counseling Guidance Semester Eight Academic Year 2019/2020 IAIN Ponorogo as many as 38 respondents (72\%) moderate stress levels. Then insomnia disorder experienced by students / i Islamic Counseling Guidance Semester Eight Academic Year 2019/2020 IAIN Ponorogo as many as 43 respondents (82\%) moderate level of insomnia. Based on hypothetical tests there is a significant relationship between stress levels and insomnia disorders at a significant level 5\% $r$ count $=0.479>$ (greater) than $r$ table $=0.266$, then Ha accepted.
\end{abstract}

Key word: stress, insomnia,

\begin{abstract}
Abstrak
Penelitian ini bertujuan untuk mengetahui tingkat stres dan gangguan insomnia yang dialami mahasiswa/i BPI semester delapan tahun akademik 2019/2020 serta mengetahui bagaimana hubungan tingkat stres dengan gangguan insomnia. Variabel dalam penelitian ini ada variabel bebas yaitu tingkat stres dan variabel terikat yaitu gangguan insomnia. Pendekatan yang digunakan dalam penelitian ini adalah pendekatan kuantitatif. Kemudian
\end{abstract}


jenis penelitiannya adalah korelasional. Sampel yang digunakan berjumlah 53 responden. Teknik pengumpulan datanya menggunakan kuesioner. Analisis data yang digunakan menggunakan uji instrument (validitas dan reliabilitas), uji statistik (statistik deskriptif dan statistik inferensial), dan uji hipotesis koefisien kontigensi. Hasil penelitian menunjukkan bahwa tingkat stres yang dialami mahasiswa/i Bimbingan Penyuluhan Islam Semester Delapan Tahun Akademik 2019/2020 IAIN Ponorogo sebanyak 38 responden $(72 \%)$ mengalami stres tingkat sedang. Kemudian gangguan insomnia yang dialami mahasiswa/i Bimbingan Penyuluhan Islam Semester Delapan Tahun Akademik 2019/2020 IAIN Ponorogo sebanyak 43 responden (82\%) mengalami insomnia tingkat sedang. Berdasarkan uji hipotesis terdapat hubungan yang signifikan antara tingkat stres dengan gangguan insomnia pada taraf signifikan 5\% r hitung $=0,479>$ (lebih besar) dari r tabel $=0,266$, maka Ha diterima.

\section{Kata kunci: stress, insomnia,}

\section{PENDAHULUAN}

Mahasiswa adalah seorang pelajar yang sedang menempuh pendidikan tinggi disebuah perguruan tinggi. Difase inilah hambatan-hambatan akan mulai mereka hadapi. Terlebih lagi ketika mereka sudah menginjak semester demi semester, maka tugas-tugas yang harus mereka kerjakanpun juga akan memiliki tingkat kesulitan yang berbeda dari semester sebelumnya. Ketika, semakin mendekati semester akhir maka mereka harus dihadapkan dengan tugas akhir salah satunya adalah skripsi. Di semester delapan atau semester akhir inilah merupakan periode penuh krisis. Tuntutan yang mereka hadapipun tidak hanya tuntutan akademik namun juga non akademik. Beberapa keadaan penuh krisis dapat menjadikan sebuah beban dan tekanan. Keadaaan stres ini dapat menimbulkan adanya resiko gangguan tidur berupa insomnia.

Dalam kamus psikologi stres diartikan sebagai suatu keadaan tertekan baik itu secara fisik maupun psikologis. ${ }^{1}$ Menurut Clonninger menyatakan, stres adalah keadaan yang membuat tegang yang terjadi ketika seseorang mendapatkan masalah atau tantangan dan belum mempunyai jalan keluarnya atau banyak pikiran yang mengganggu seseorang terhadap sesuatu yang akan dilakukannya. ${ }^{2}$ Sebagai mahasiswa dan mahasiswi, kita tentunya

\footnotetext{
${ }^{1}$ Akmal Mizan Makarim, Endah Kurniawati P, Hubungan Antara Stres Kerja Dengan Pemilihan Strategi Coping Pada Perawat Di Rumah Sakit Islam Unisma Malang, Jurnal Psikoislamika, Vol 11, No 1, 2014, 24

${ }^{2}$ I Wayan Candra, dkk, Psikologi Landasan Keilmuan Praktik Keperawatan Jiwa (Yogyakarta: ANDI, 2017), 104
} 
memiliki kontribusi yang besar untuk kemajuan dunia pendidikan. Kemudian banyak tugas yang harus diemban dan dikerjakan oleh mahasiswa dan mahasiswi, terlebih lagi ketika sudah menginjak semester demi semester akan banyak tugas-tugas yang tingkat kesulitannya akan jauh berbeda dari semester sebelumnya. Selain tugas perkuliahan, mereka juga akan dihadapkan oleh tantangan-tantangan kehidupan diluar kampus, seperti permasalahan keluarga, organisasi, ataupun pekerjaan.

Seorang psikolog, Arnett mengatakan bahwa anak muda usia 18-25 tahun, termasuk mahasiswa dan mahasiswi berada pada suatu tahapan perkembangan emerging adulthood. Tahapan ini relatif baru karena mahasiswa dan mahasiswi berada pada suatu posisi antara masa remaja akhir dan dewasa awal. Tahapan ini dicirikan atas lima hal yaitu: ${ }^{3}$ masa eksplorasi identitas karier dan pasangan, masa ketidakstabilan eksplorasi identitas, masa fokus pada kemandirian dan kebebasan diri, masa antara remaja dan dewasa, masa optimisme terhadapan harapan dan cita-cita.

Menurut Maramis , ada empat sumber atau penyebab stres psikologis, yaitu: ${ }^{4}$

1. Frustasi, merupakan keadaan yang timbul akibat tujuan yang tidak dapat tercapai karena adanya aral melintang atau hambatan.

2. Konflik, timbul karena tidak bisa memilih antara dua atau lebih macam keinginan, kebutuhan, atau tujuan.

3. Tekanan, timbul sebagai akibat tuntutan hidup sehari-hari.

4. Krisis, merupakan keadaan yang mendadak, yang menimbulkan stres pada individu

\footnotetext{
${ }^{3}$ Zamroni, Prevalensi Stres Akademik Mahasiswa, Jurnal Psikoislamika Vol 12, No 2, 2015,

${ }^{4}$ Sunaryo, Psikologi Untuk Keperawatan, 218.
} 
Menurut Taylor Gejala- gejala tersebut meliputi: ${ }^{55}$

1. Aspek emosional (perasaan). Meliputi merasa cemas (feeling anxious), merasa ketakutan (feeling scared), merasa mudah marah (feeling irratable), merasa suka murung (feeling moody), dan merasa tidak mampu menanggulangi (feeling of inability to cope).

2. Aspek kognitif (pikiran). Meliputi penghargaan atas diri rendah (low self esteem), takut gagal (fear failure), tidak mampu berkonsentrasi (inability to concentrate), mudah bertindak memalukan (embarrassing easily), khawatir akan masa depannya (worrying about the future), mudah lupa (forget fulness), dan emosi tidak stabil (emotional instability).

3. Aspek perilaku sosial. Meliputi jika berbicara gagap atau gugup dan kesukaran bicara lainnya (stuttering and other speech difficulties), enggan bekerja sama (uncooperative activities), tidak mampu rileks (inability to relax), menangis tanpa alasan yang jelas (crying for no apparent reason), bertindak sesuka hati atau impulsif (acting impulsively), mudah kaget atau terkejut (startling easily), menggertakkan gigi (grinding teeth), frekuensi rokok meningkat (increasing smoking), penggunaan obat-obatan dan alkohol (increasing use of drugs and alcohol), mudah celaka (being accident prone), dan kehilangan selera makan (losing appetite or overeating).

4. Aspek fisiologis. Meliputi detak jantung meningkat, berkeringat, menggigil atau bergemetar, mulut dan kerongkongan kering, gelisah atau gugup, mudah letih, sering buang air kecil, bermasalah dalam tidur, diare dan muntah, sembelit, sakit kepala, tekanan darah tinggi, dan sakit pada leher dan atau punggung bawah.

\footnotetext{
${ }^{5}$ Indra Gunawan, Yahya, Pelatihan Kaligrafi Terhadap Tingkat Stres Narapidana, Jurnal Psikoislamika, Vol 13, No 1, 2016, 41- 42
} 
Pengertian tidur sendiri adalah suatu kondisi yang mulai terjadi kalau orang menutup mata dan kehilangan kontak dengan lingkungannya, kemudian diakhiri dengan timbulnya kembali kesadarannya terhadap peristiwa yang ada disekitarnya. ${ }^{6}$ Gangguan tidur adalah keadaan yang mempengaruhi kemampuan untuk tidur dengan baik dan memadai. Keadaan tersebut bisa dipengaruhi oleh masalah kesehatan ataupun stres. ${ }^{7}$ Insomnia adalah suatu keadaan yang menyebabkan individu tidak mampu mendapatkan tidur yang adekuat, baik secara kualitas maupun kuantitas, sehingga individu tersebut hanya tidur sebentar atau susah tidur. ${ }^{8}$ Sedangkan Joewana mendefinisikan gangguan insomnia sebagai suatu keluhan tentang kurangnya kualitas tidur yang disebabkan oleh satu dari sulit memasuki tidur, sering terbangun malam kemudian sulit untuk tidur kembali, bangun terlalu pagi, dan tidur yang tidak nyenyak. ${ }^{9}$ Kualitas tidur diartikan sebagai suatu keadaan tidur yang dijalani seorang individu menghasilkan kesegaran dan kebugaraan saat terbangun. Sedangkan kuantitas sendiri diartikan sebagai lamanya waktu atau jumlah jam yang digunakan untuk tidur. ${ }^{10}$ Insomnia dapat disebabkan oleh beberapa faktor, diantaranya: ${ }^{11}$

\section{Masalah Psikis}

Dalam buku Kesehatan Mental, faktor psikologis yang menyebabkan insomnia adalah kegelisahan, ketakutan, perasaan bersalah, dan perasaan cemas atau stres sebagai antisipasi terhadap peristiwa-peristiwa yang datang. ${ }^{12}$

Sedangkan dalam jurnal kesehatan Soedirman menyatakan bahwa gangguan insomnia terjadi karena adanya ketegangan otot, ketika seseorang mengalami stres maka beberapa otot akan mengalami ketegangan, yang akhirnya saraf simpatis membuat seseorang tidak dapat santai sehingga tidak dapat memunculkan rasa kantuk. ${ }^{13}$

\footnotetext{
${ }^{6}$ Agus Mukholid, Pendidikan Jasmani Olahraga dan Kesehatan, (Yudistira, 2007), 181

${ }^{7}$ Kris H. Timotius, Otak dan Perilaku, (Yogyakarta: ANDI, 2018), hal 110-111

${ }^{8}$ Musrifatul Uliyah, A. Aziz Alimul Hidayat, Keterampilan Dasar Praktik Klinik untuk Kebidanan Edisi 2,116

9 Taat Sumedi, dkk, Pengaruh Senam LansiaTerhadap Penurunan Skala Insomnia Pada Lansia Di Panti Wredha Dewanata Cilapacap, Jurnal Keperawatan Soedirman, Vol 5, No 1, 2010,14

${ }^{10}$ Sugiono, dkk, Ergonomi Untuk Pemula (Prinsip Dasar dan Aplikasinya), (Malang: UB Press, 2018), 114

${ }^{11}$ Herri Zan Pieter, dkk, Pengantar Psikopatologi Untuk Keperawatan, 346

12 Yustinus Semium, OFM, Kesehatan Mental 2, (Yogyakarta: Kanisius, 2006), 207

13 Taat Sumedi, dkk, Pengaruh Senam LansiaTerhadap Penurunan Skala Insomnia Pada

Lansia Di Panti Wredha Dewanata Cilapacap, Jurnal Keperawatan Soedirman, Vol 5, No 1, 2010,14
} 


\section{Penyalahgunaan alkohol dan obat-obatan}

Antara penggunaan alkohol dan obat-obatan saling berkaitan dan dianggap menjadi salah satu faktor penyebab gangguan tidur. Dalam jumlah sedikit mengkonsumsi alkohol dianggap dapat membantu rasa kantuk, tetapi sekaligus mengintrupsi/memutus tidur. Tidur yang terintrupsi akan menimbulkan kecemasan yang pada akhirnya akan membuat orang berulang-ulang meminum alkohol. Obat juga dapat mempengaruhi proses tidur, beberapa jenis obat yang mempengaruhi proses tidur, seperti jenis golongan obat diuretic yang dapat menyebabkan insomnia, antidepresan yang dapat menekan REM, golongan beta bloker berefek pada timbulnya insomnia, dan kafein dapat meningkatkan saraf simpatis sehingga menyebabkan kesulitan untuk tidur. ${ }^{14}$

\section{Usia}

Keluhan insomnia sangat berbeda-beda pada setiap orang yang disertai dengan perbedaan tingkat usia. Persentasi individu mengeluhkan masalah gangguan tidur, khususnya insomnia mulai meningkat ketika dia memasuki usia dewasa muda yaitu usia 18 tahun keatas. Angka yang lebih tinggi dalam laporan- laporan mengenai masalah tidur adalah pada orang dewasa akhir atau pada lansia. Pada usia 18 - 40 tahun kebutuhan tidur yang ideal adalah 7 -8 jam/ hari.

4. Memiliki penyakit

Keadaan tubuh yang tidak sehat juga dapat mempengaruhi tidur seseorang, biasanya dengan keluhan sakit pusing, migraine, dan juga demam membuat mereka mengalami insomnia.

\section{Lingkungan}

Orang-orang yang sedang dirawat di rumah sakit sering kali mengalami kesulitan tidur, karena selain menggunakan obat-obatannya dia juga terpengaruh oleh keadaan lingkungan, suhu, suara, dan cahaya yang sangat berbeda dengan kondisi rumahnya.

\footnotetext{
${ }^{14}$ Musrifatul Uliyah, A. Aziz Alimul Hidayat, Keterampilan Dasar Praktik Klinik Untuk Kebidanan Edisi 2, 115
} 


\section{METODE}

Penelitian ini termasuk dalam penelitian kuantitatif, dengan jenis korelasional. Variabel bebasnya yaitu stres dan variabel terikatnya gangguan insomnia. Subjek dalam penelitian ini adalah mahasiswa/mahasiswi Bimbingan Penyuluhan Islam semester delapan yang masih aktif dengan jumlah 53 responden. Teknik pengumpulan datanya menggunakan angket, dengan skala pengukurannya yaitu skala likert. Dimana dengan skala likert ini variabel yang akan diukur dijabarkan menjadi indikator variabel. Kemudian angket yang telah dibuat dilakukan uji coba terlebih dahulu untuk menguji validitas dan reliabilitasnya. Uji statistik yang digunakan adalah statsitik deskriptif dan statistik inferensial. Untuk uji hipotesisnya menggunakan uji koefisien kontigensi.

Pada uji statistik deskriptif untuk mencari skor tinggi, sedang, dan rendah maka perlu mencari nilai mean dan standart deviasi. Sedangkan uji statistik inferensialnya adalah dengan melakukan uji normalitas dan uji linearitas. Dalam uji normalitas menggunkan rumus kolmogorof smirnof dengan taraf signifikansi 5\%, dengan sebaran data dikatakan normal jika memiliki nilai signnifikansi lebih besar dari 0,05 ( $\mathrm{sig}>0,05$ ), dan uji linearitas menggunakan Anova dengan ketetapan jika nilai sig deviation from linearity lebih besar (>) 0,05, maka terdapat hubungan yang linear. Dalam penelitian ini untuk menguji normalitas dan linearitas peneliti menggunakan aplikasi IBS Statistic SPSS versi 21. Kemudian untuk mencari kategori skor tinggi, sedang, dan rendah yaitu dengan rumus:

Tinggi $\mathrm{X}>(\mathrm{M}+1 . \mathrm{SD})$

Sedang $(M-1 . S D)<X<(M+1 . S D)$ Rendah $X<(M-1 . S D)$

Dimana semakin tinggi skor maka responden akan lebih kuat atau tahan terhadap stres dan gangguan insomnia. Namun jika semakin rendah skor makan akan semakin rentan terhadap stres dan insomnia. 
Tabel 1

\section{Data untuk Koefisien Kontingensi}

\begin{tabular}{|l|l|l|l|l|}
\hline & 1 & 2 & 3 & Total \\
\hline 1 & A & B & C & rN1 \\
\hline 2 & D & E & F & rN2 \\
\hline 3 & G & H & I & rN3 \\
\hline Total & $\mathrm{cN}$ & $\mathrm{cN} 2$ & $\mathrm{cN}$ & $\mathrm{N}$ \\
\hline
\end{tabular}

\section{HASIL DAN PEMBAHASAN}

1. Uji statistik deskriptif

Untuk variabel Tingkat Stres hasil mean yaitu 74,26 dan standart deviasinya 10,93. Dengan hasil Tingkat Stres sebagai berikut:

\section{Tabel 2}

\section{Tingkat Stres Mahasiswa/i Bimbingan Penyuluhan Islam Semester Delapan} Tahun Akademik 2019/2020 IAIN Ponorogo

\begin{tabular}{|l|c|l|}
\hline Tingkat stres & Frekuensi & Persentase \\
\hline Tinggi & 7 & $13 \%$ \\
\hline Sedang & 38 & $72 \%$ \\
\hline Rendah & 8 & $15 \%$ \\
\hline Jumlah & 53 & $100 \%$ \\
\hline
\end{tabular}

Dari data di atas maka, dapat kita ketahui bahwa jumlah responden yang mengalami stres tingkat tinggi yaitu terdapat 7 orang, tingkat sedang 38 orang, dan tingkat rendah 8 orang.

Untuk variabel Gangguan Insomnia, hasil mean yaitu 34,71 dan standart deviasinya 5,15. Dengan hasil Gangguan Insomnia sebagai berikut: 


\section{Tabel 3}

\section{Gangguan InsomniaMahasiswa/i Bimbingan Penyuluhan Islam Semester Delapan Tahun Akademik 2019/2020 IAIN Ponorogo}

\begin{tabular}{|c|c|c|}
\hline $\begin{array}{l}\text { Gangguan } \\
\text { insomnia }\end{array}$ & Frekuensi & Persentase \\
\hline Tinggi & 5 & $9 \%$ \\
\hline Sedang & 43 & $82 \%$ \\
\hline Rendah & 5 & $9 \%$ \\
\hline Jumlah & 53 & $100 \%$ \\
\hline
\end{tabular}

Dari data di atas dapat kita ketahui bahwa jumlah responden yang mengalami gangguan insomnia tinggi yaitu terdapat 5 orang, tingkat sedang 43 orang, dan tingkat rendah 5 orang.

2. Uji statistik inferensial

a. Uji normalitas

Berdasarkan hasil uji normalitas diketahui nilai signifikansi 0,868 lebih dari (>) 0,05 maka dapat dikatakan bahwa nilai residual berdistribusi normal.

b. Uji linearitas

Berdasarkan tabel diatas dapat diketahui bahwa nilai sig deviation from linearity yaitu 0,184. Karena nilai 0,184 >0,05, maka terdapat hubungan yang linear antara variabel tingkat stres dan variabel gangguan insomnia. 
3. Uji hipotesis

Tabel 4

Nilai korelasi tingkat Stres Dengan Gangguan Insomnia

\begin{tabular}{|l|l|l|l|l|}
\hline $\begin{array}{l}\text { Insomnia } \\
\text { Tingkat } \\
\text { stres }\end{array}$ & Tinggi & Sedang & Rendah & Jml \\
\hline Tinggi & 2 & 5 & 0 & 7 \\
\hline Sedang & 3 & 33 & 2 & 38 \\
\hline Rendah & 0 & 5 & 3 & 8 \\
\hline Jumlah & 5 & 43 & 5 & 53 \\
\hline
\end{tabular}

Dari tabel diatas kemudian memasukkan angka-angka dari tabel nilai korelasi kontigensi kedalam tabel perhitungan, sebagai berikut:

Tabel 5

Tabel perhitungan $\chi^{2}$

\begin{tabular}{|r|r|r|c|c|c|}
\hline Sel & $\mathbf{F}$ & $\mathbf{F}_{\mathbf{t}}$ & $\mathbf{f}_{\mathbf{0}} \mathbf{f}_{\mathbf{t}}$ & $\left(\mathbf{f}_{\mathbf{0}}-\mathbf{f}_{\mathbf{t}}\right)^{\mathbf{2}}$ & \\
\hline 1 & 2 & 0,66037735 & 1,339622642 & 1,79458882 & 2,71752021 \\
\hline 2 & 5 & 5,67924528 & - & 0,46137415 & 0,08123863 \\
\hline 3 & 0 & 0,66037735 & - & 0,43609825 & 0,66037735 \\
\hline 4 & 3 & 3,58490566 & $-0,58490566$ & 0,34211463 & 0,09543197 \\
\hline 5 & 3 & 30,8301886 & 2,169811321 & 4,70808116 & 0,15271009 \\
\hline 6 & 2 & 3,58490566 & $-1,58490566$ & 2,51192595 & 0,70069513 \\
\hline 7 & 0 & 0,75471698 & - & 0,56959772 & 0,75471698 \\
\hline 8 & 5 & 6,49056603 & - & 2,22178711 & 0,34231022 \\
\hline 9 & 3 & 0,75471698 & 2,245283019 & 5,04129583 & 6,67971698 \\
\hline Tot & & & & & \begin{tabular}{c}
$\chi^{2}$ \\
\hline
\end{tabular} \\
\hline
\end{tabular}

Setelah tabel dipastikan terisi semua dan didapatkan nilai $\chi^{2}=12,18471761$, selanjutnya nilai $\chi^{2}$ harus dirubah kedalam nilai koefisien kontigensi. Nilai $C=0,432349379$. Kemudian nilai Phi sebesar 0,47947923.

Setelah nilai koefisien korelasi diketahui, kemudian menganalisa interpretasinya, yaitu mencari $\mathrm{db}=\mathrm{Nr}-\mathrm{nr}=53-2=51$, selanjutnya dikonsultasikan dengan tabel nilai " $\mathrm{r}$ " product moment, karena db 51 tidak ada, maka menggunakan yang mendekati yaitu $\mathrm{db}=$ 
55. Pada taraf signifikan $5 \% \mathrm{r}$ hitung $=0,479$ dan $\mathrm{r}$ tabel $=0,266$ sehingga, $\mathrm{r}$ hitung $>\mathrm{r}$ tabel maka Ha diterima dan Ho ditolak.

Penelitian ini membuktikan teori dari Herri Zan Pieter yang menyatakan bahwa keadaan sulit tidur atau insomnia dapat disebabkan oleh faktor penyebab masalah psikis yaitu berupa stres. ${ }^{15}$ Hal ini didukung juga dalam jurnal kesehatan Soedirman yang menyatakan bahwa gangguan insomnia terjadi karena adanya ketegangan otot, ketika seseorang mengalami stres. Karena stres tersebut, maka beberapa otot akan mengalami ketegangan, yang akhirnya saraf simpatis menjadi tidak dapat santai sehingga tidak dapat memunculkan rasa kantuk. ${ }^{16}$

${ }^{15}$ Herri Zan Pieter, dkk, Pengantar psikopatologi Untuk Keperawatan, 346

16 Taat Sumedi, dkk, Pengaruh Senam LansiaTerhadap Penurunan Skala Insomnia Pada Lansia Di Panti Wredha Dewanata Cilapacap, Jurnal Keperawatan Soedirman, Vol 5, No 1, 2010,1 


\section{PENUTUP}

Berdasarkan hasil penelitian dan pembahasan diatas, peneliti menyimpulkan tiga hal yang berkaitan dengan rumusan masalah yaitu:

1. Tingkat stres yang dialami mahasiswa/i Bimbingan Penyuluhan Islam Semester Delapan Tahun Akademik 2019/2020 IAIN Ponorogo, yaitu masuk dalam tingkat sedang. Hal ini dapat diketahui dan dibuktikan lewat analisis data yang telah dilakukan yaitu sebanyak 7 responden (13\%) mengalami tingkat stres tinggi, sebanyak 38 responden $(72 \%)$ mengalami tingkat stres sedang, dan sebanyak 8 responden (15\%) mengalami tingkat stres rendah.

2. Gangguan insomnia yang dialami mahasiswa/i Bimbingan Penyuluhan Islam Semester Delapan Tahun Akademik 2019/2020 IAIN Ponorogo, yaitu masuk dalam tingkat insomnia sedang. Hal ini dapat diketahui dan dibuktikan dari hasil analisis data yang telah dilakukan yaitu sebanyak 5 responden (9\%) mengalami insomnia tingkat tinggi, sebanyak 43 responden (82\%) mengalami insomnia tingkat sedang, dan sebanyak 5 responden $(9 \%)$ mengalami insomnia tingkat rendah.

3. Adanya hubungan yang signifikan antara tingkat stres dengan gangguan insomnia yang dialami mahasiswa/i Bimbingan Penyuluhan Islam Semester Delapan Tahun Akademik 2019/2020 IAIN Ponorogo. Hal ini sesuai dengan hasil perhitungan hipotesis yaitu pada taraf signifikan 5\% $\mathrm{r}$ hitung $=0,479>$ (lebih besar) dari $\mathrm{r}$ table $=0,266$, maka Ha diterima. 


\section{DAFTAR RUJUKAN}

Candra,I Wayan dkk. 2017. Psikologi Landasan Keilmuan Praktik Keperawatan Jiwa. Yogyakarta: ANDI

Gunawan, Indra. Yahya. 2016. Pelatihan Kaligrafi Terhadap Tingkat Stres Narapidana. Jurnal Psikoislamika, Vol 13, No 1, 2016

Makarim, Akmal Mizan, dkk. 2014. Hubungan Antara Stres Kerja Dengan Pemilihan Strategi Coping Pada Perawat Di Rumah Sakit Islam Unisma Malang. Jurnal Psikoislamika. Vol 11, No 1

Mukholid, Agus. 2007. Pendidikan Jasmani Olahraga dan Kesehatan. Yudistira

Pieter, Herri Zan , dkk. 2011. Pengantar Psikopatologi Untuk Keperawatan. Jakarta: Kencana

Semium, Yustinus. OFM. 2006. Kesehatan Mental 2. Yogyakarta: Kanisius

Sugiono, dkk. 2018. Ergonomi Untuk Pemula (Prinsip Dasar dan Aplikasinya). Malang: UB Press

Sumedi , Taat, dkk. 2010. Pengaruh Senam LansiaTerhadap Penurunan Skala Insomnia Pada Lansia Di Panti Wredha Dewanata Cilapacap, Jurnal Keperawatan Soedirman, Vol 5, No 1

Sunaryo. 2004. Psikologi Untuk Keperawatan . Jakarta: Kedokteran EGC Timotius, Kris H. 2018. Otak dan Perilaku. Yogyakarta: ANDI

Uliyah, Musrifatul, dkk. 2008. Keterampilan Dasar Praktik Klinik untuk Kebidanan Edisi 2. Jakarta: Salemba Medika

Zamroni. 2015. Prevalensi Stres Akademik Mahasiswa. Jurnal Psikoislamika Vol 12, No 2 